S. Kopashynskii ${ }^{1}$, O. Serpukhov ${ }^{2}$, H. Makogon ${ }^{2}$, H. Karakurkchi², O. Klimov², Yu. Babkin ${ }^{2}$

${ }^{1}$ The National Defense University of Ukraine named after Ivan Cherniakhovskyi, Kyiv, Ukraine

${ }^{2}$ Military Institute of Tank Troops of National Technical University "KhPI", Kharkiv, Ukraine

\title{
INVESTIGATION OF THE INFLUENCE OF OPERATIONAL-TACTICAL AND MILITARY-GEOGRAPHICAL FACTORS OF THE COMBAT AREA ON THE FUNCTIONING OF ELEMENTS OF THE ARMORED WEAPONS AND MILITARY EQUIPMENT RECOVERY SYSTEM
}

\begin{abstract}
The subject matter of the article is the influence of operational-tactical and military-geographical factors of the combat area on the functioning of elements of the system for restoring armored weapons and military equipment during combat operations in modern conditions. The goal of the study is investigation of the correlation effects between operational-tactical and military-geographical factors of the combat area on the functioning of the armored weapons and military equipment recovery system. The tasks to be solved are: to analyze the influences of the factors of the combat area on the functioning of the system of restoration of armored weapons and military equipment during the performance of the Armed Forces missions by purpose; form formal sets of conditions and factors and elements and functional links of the system of armored weapons recovery and military equipment subject to their influence; calculate the factor loadings of each factor and construct correlation Pleiades of influence. General scientific and special methods of scientific knowledge are used. The method of hierarchy analysis, mathematical apparatus of probability theory and multidimensional statistical analysis were used. The following results are obtained. Operational-tactical and military-geographical factors of the area of operations and elements the functional relationships between the recovery system of armored weapons and military equipment are formally represented as sets of random variables, and the significance of each factor is expressed by the numerical value of the factor load. Based on the results of correlation and factor analysis, correlation Pleiades are constructed, which provide tools for algorithmic accounting of the essence and qualitative characteristics of the influence of factors in managing the renewal of armored weapons and military equipment. Conclusions. Operational-tactical and military-geographical factors for any region have an impact on the functioning of the system for restoring armored weapons and military equipment, different both in terms of semantic loads and the results of actions on individual elements of the system. Based on the results of factor analysis, the significance of the influence of each factor can be expressed as a numerical value of the factor load. The influence of both military-geographical and operationaltactical factors of the combat area and the quality of functioning of elements of the recovery system of armored weapons and military equipment correlate with each other. Correlation Pleiades of influence of military-geographical and operational-tactical factors of the combat area provide tools for managing the renewal of armored weapons and military equipment.
\end{abstract}

Keywords: restoration of armored weapons and military equipment; operational-tactical and military-geographical factors of the area of hostilities; factor analysis; correlation Pleiades.

\section{Introduction}

Formulation of the problem and research tasks. Changing the nature of modern military conflicts, improving existing ones and the emergence of new forms of use of troops (forces) require the introduction of new standards in the Armed Forces (AF) of Ukraine aimed not only at the purposeful acquisition by military authorities and military units of certain combat forces and means to perform a specific list of tasks, but also to organize the restoration of armored weapons and military equipment (AWME) whose structure and interelemental relationships are justified by the conditions and factors that affect it.

At the present level of society development both operational-tactical and military-geographical factors have impacts on the functioning of the system of reconstruction of the AWME, different both in content load and in time and the consequences of action on individual elements of the system. In this regard, the effectiveness of the functioning of the AWME system depends not only on the correct assessment of the qualitative and quantitative characteristics of the impact on one or another factor, but also on the consideration of the relationships between them.

The above induces the authors to consider it relevant to study the correlation effects on the functioning of the system of renewal of arms and military equipment of the operational grouping of troops (forces) by operational-tactical and militarygeographical conditions and factors in local wars and armed conflicts of the present.

Analysis of recent research and publications on the above issues shows that the features of the AF of Ukrainian performance for their intended tasks purpose outline the main problems and directions of development of the justification theory of decisions on the AWME recovery system management.

Experts also describe the consequences of the influence of a particular factor on the operation of weapons and military equipment during the preparation and use of troops (forces).

Using of such research results can greatly improve the technical support troops (forces) quality as a whole and the functioning of the AWME recovery system particularly. Nevertheless, factor analysis can provide a toolkit for algorithmic consideration of the nature and qualitative characteristics of the influence of factors in managing the restoration of AWME [1-3].

The goal of the study is investigation of the correlation effects between operational-tactical and military-geographical factors of the combat area on the functioning of the armored weapons and military equipment recovery system. To achieve this goal the 
following research tasks are solved: : to analyze the influences of the factors of the combat area on the functioning of the system of restoration of armored weapons and military equipment during the performance of the Armed Forces missions by purpose; form formal sets of conditions and factors and elements and functional links of the system of armored weapons recovery and military equipment subject to their influence; calculate the factor loadings of each factor and construct correlation Pleiades of influence.

\section{Main material}

1. The number, composition and training of personnel, the AWME number and quality, the availability of reserves of military-technical equipment and the possibility of their recovery, location and nature of the enemy's actions are considered as operational and tactical factors affecting the functioning of the AWME recovery system. and opportunities to interact with other power structures.

Thus, the critically low staffing of repair and rehabilitation bodies to a large extent contributes to the reduction of production capacity for the repair of AWME ultimately leads to low performance.

Shortcomings in the training of personnel, poor knowledge of driver mechanics on the device and operation of units, operation of machines had a negative impact on the AWME quality involved in performing tasks for the intended purpose.

The effectiveness of the operation of the AWME recovery system certainly depends on the correct assessment of the qualitative and quantitative status of weapons and equipment that will be subject to maintenance and repair, that is, forecasting task volumes for evacuation units and repair and restoration agencies.

According to statistics, the main AWME malfunctions during decommissioning tasks are predominantly random and hardly predictable, which causes the receipt of failures in the AWME recovery system in the form of a flow of orders with variable intensity. In general, the condition and completeness of the AWME in a certain way influences the choice of a rational method of restoration of details, since it requires consideration of technological and economic features of the Ministry of Defense of Ukraine specific repair enterprises $[2,3]$.

The existing military-technical equipment resupply system is morally outdated and has shortcomings that impede the timely implementation of AWME restoration measures.

Lack of training, intelligence equipment, problems with clevises and targeting led to the fact that the consumption of ammunition had at times exceeded the standards prescribed for the respective purposes in the post- Soviet courses of fire.

Obviously, during combat operations, weapons and military equipment will fail due to the fire influence on the troops by the enemy. Given the location and the nature of the enemy's actions in modern conditions, the organization of recovery should be aimed at restoring the maximum number of AWME at the site of failure (at checkpoints, fighting positions, areas of failure), and during the march and regrouping, usually after the evacuation of it to the national team point of damaged machines.

During the advance of troops, it is advisable for repair and evacuation groups to act as closing marching columns in order to restore the mobility of AWME samples or evacuating them to an area where it is possible to organize repairs. These circumstances indicate the need for rapid response to changes in the technical situation, which is possible if a reliable management system and the manifestation of all-round creative activity of commanders to organize the AWME restoration.

Equally significant for the functioning of the AWME recovery system are the military-geographical factors of the area of hostilities and the level of operational equipment of the territory. These circumstances complicate the process of organizing technical reconnaissance and evacuation of damaged equipment during combat operations.

The next factor that has an impact on the functioning of the AWME recovery system when performing tasks for their intended purpose is naturally considered to be climatic conditions. These circumstances should be taken into account when organizing the AWME operation (GB, cooling and lubrication systems, etc.), evacuation of damaged equipment samples (identification of escape routes, equipping repair and evacuation groups and repairs in the field (placement of repair tools on the ground, their deployment, equipment of work stations, setting up the production process).

As we can see, both operational-tactical and military-geographical factors that influence the nature of combat operations and the AWME recovery system have different characteristics in time and space. The temporal multiplicity (frequency of use) of such information in managing the system of recovery of AWME will be less in comparison with the variable information. Variable information can be attributed to the current weather forecast, the state of green space spaces in accordance with the season, the availability of AWME stocks, etc. Similarly, for each factor, the consequences of the aftereffect, the number of elements and functional relationships of the AWME recovery system fall under their influence, the degree and scale of action in space are different.

Thus, at the current level of society development both operational-tactical and military-geographical factors for any region have impacts on the functioning of the system of restoration of military-industrial complex, different characteristics both in content load and the consequences of actions on individual elements of the system.

2. We define the following set $F O=$ $=\left\{f o_{j}\right\}, j=\overline{1, m}, \quad(m=5)$ of operational and tactical factors to be investigated:

$f_{1}-$ quantitative and qualitative status of weapons;

$\mathrm{fo}_{2}$ - number and training of personnel; 
$f_{3}-$ availability of the military-technical equipment resupply; actions;

$\mathrm{fo}_{4}$ - the location and nature of the enemy's

$f_{5}$ - possibilities of interaction with other power structures.

By analogy, the set $F G=\left\{f g_{j}\right\}, j=\overline{1, m} \quad(m=5)$

of military-geographical factors will contain the following elements:

$f g_{1}$ - locality;

$f g_{2}$ - climate conditions;

$\mathrm{fg}_{3}$ - territory operational equipment level;

$\mathrm{fg}_{4}$ - combat area infrastructure;

$f g_{5}$ - the other states' ability to support or participate on the side of the enemy.

We will consider the elements of sets as random variables.

Similarly, we distinguish the following characteristics of a factor influence:

$a_{1}$ - multiplicity and duration of action;

$a_{2}$ - the number of elements and functional links of the AWME recovery system are affected;

$a_{3}$ - degree (intensity) of action;

$a_{4}$ - the spatial scale of the action;

$a_{5}$ - aftereffects.

In the theory of multidimensional statistical analysis, the coefficients $a_{k}, k=\overline{1, p},(p=5)$ are called factor loadings characterize the significance of the influence of each factor [4].

Each of these factors influences the functioning of the AWME recovery system, namely its individual elements. For the study let's select the following:

$V=\left\{v_{j}\right\}, j=\overline{1, m},(m=5)$.

$v_{1}-$ state of technical intelligence

implementation;

$v_{2}$ - organization of the AWME evacuation;

$v_{3}$ - using the technological potential of repair and restoration units;

$v_{4}-$ AWME protection, security and defense measures;

$v_{5}$ - creation and replenishment of militarytechnical equipment stocks.

To simplify the mathematical calculations, we assume that the value $v o_{j i}$ will characterize the influence of the j-th operational-tactical factor on the functioning of the $i$-th element of the AWME recovery system and can be calculated by the expression

$$
v o_{j i}=\sum_{k=1}^{p} a_{j k} f o_{k i},
$$

$$
i=1,2, \ldots, n ; j=1,2, \ldots, m ; k=1,2, \ldots, p .
$$

here $a_{j k}$ - elements of the operational-tactical factors loadings matrix $A=\left\{a_{j k}\right\}, j=1,2, \ldots m ; k=1,2, \ldots . p$.
Analytical determination of values for calculations is proposed to be carried out both by the results of the expert survey and by the mathematical apparatus of probability theory, since certain characteristics can be considered as discrete or continuous random variables (multiplicity and the duration of the action, the number of failures in the AWME samples, etc.).

In order to eliminate the influence of dimensionality and ensure comparison of factors, the matrix of initial data was normalized by standardization [5].

Thus, it is natural to require the condition

$$
\sum_{k=1}^{p} a_{j k}=1, k=1,2, \ldots, p .
$$

The result of such calculations is the matrix A.

$$
A=\left(\begin{array}{lllll}
0,17 & 0,20 & 0,23 & 0,14 & 0,26 \\
0,22 & 0,24 & 0,19 & 0,16 & 0,19 \\
0,21 & 0,16 & 0,18 & 0,19 & 0,27 \\
0,25 & 0,22 & 0,14 & 0,11 & 0,28 \\
0,25 & 0,20 & 0,20 & 0,18 & 0,17
\end{array}\right)
$$

For similar reasons, the matrix $\mathrm{B}$ of factor loadings of military-geographical factors on the functioning of the AWME recovery system was calculated

$$
B=\left(\begin{array}{ccccc}
0,1 & 0,14 & 0,22 & 0,24 & 0,21 \\
0,27 & 0,16 & 0,25 & 0,15 & 0,17 \\
0,19 & 0,23 & 0,19 & 0,20 & 0,19 \\
0,16 & 0,22 & 0,19 & 0,17 & 0,26 \\
0,15 & 0,26 & 0,21 & 0,18 & 0,20
\end{array}\right)
$$

In this case, an influence indicator of the $j$-th military-geographical factor on the functioning of the $i$ th element of the AWME recovery system will be a value $v g_{j i}$ that can be calculated by the expression

$$
v g_{j i}=\sum_{k=1}^{p} b_{j k} f g_{k i}
$$

$$
i=1,2, \ldots, n ; j=1,2, \ldots, m ; k=1,2, \ldots, p .
$$

here $B=\left\{b_{j k}\right\}, j=1,2, \ldots m ; k=1,, 2, \ldots . p$ - militarygeographical factor loadings matrix.

Thus, the matrix $V O=\left\{v o_{j i}\right\}, \quad i=1,2, \ldots, n$, $j=1,2, \ldots m$ will characterize the influence of the $j$-th operational-tactical factor on the functioning of the $i$-th element of the AWME recovery system.

The matrix $V G=\left\{v g_{j i}\right\}, i=1,2, \ldots, n, j=1,2, \ldots m$ will characterize the influence $j$ - го militarygeographical factor on the functioning of the $i$-th element of the AWME recovery system.

Values $F O=\left\{f o_{j}\right\}$ and $F G=\left\{f g_{j}\right\}, j=\overline{1, m}$ were calculated on the basis of the results of statistical processing and expert surveys on the theory of probabilities and modifications of the method of hierarchy analysis.

The results obtained were used to calculate the elements of the matrices $V O=\left\{v o_{j i}\right\}$ and $V G=\left\{v g_{j i}\right\}$, 
$i=1,2, \ldots, n, \quad j=1,2, \ldots m$ by the way by applying formulas (1) and (2) used for further correlation analysis.

In order to achieve greater clarity of statements about correlated values $f o, f g$ та $v o, v g$ crosscorrelation matrices were used. They are: $R O=\left\{r_{j i}\right\}$ and $R G=\left\{r g_{j i}\right\}, i=1,2, \ldots, n, j=1,2, \ldots m$ [6-9].

$$
\begin{aligned}
R G & =\left(\begin{array}{ccccc}
0,56 & 0,88 & 0,18 & 0,80 & 0,31 \\
0,45 & 0,63 & 0,29 & 0,3 & 0,2 \\
0,72 & 0,89 & 0,57 & 0,54 & 0,3 \\
0,52 & 0,79 & 0,84 & 0,7 & 0,67 \\
-0,57 & -0,61 & -0,50 & -0,91 & -0,73
\end{array}\right), \\
R O & =\left(\begin{array}{ccccc}
0,82 & 0,68 & 0,83 & 0,66 & 0,69 \\
0,66 & 0,73 & 0,81 & 0,6 & 0,4 \\
0,55 & 0,65 & 0,81 & 0,41 & 0,91 \\
-0,69 & -0,78 & -0,64 & -0,92 & -0,8 \\
0,62 & 0,59 & 0,45 & 0,46 & 0,57
\end{array}\right) .
\end{aligned}
$$

The results of correlation and factor analysis showed that the influences of both military-geographical and operational-tactical factors of the combat area and the quality of functioning of the elements of the system of recovery of military-industrial complex are correlated with each other. Correlation analysis (Pearson's criterion was used) of indicators of influence of military-

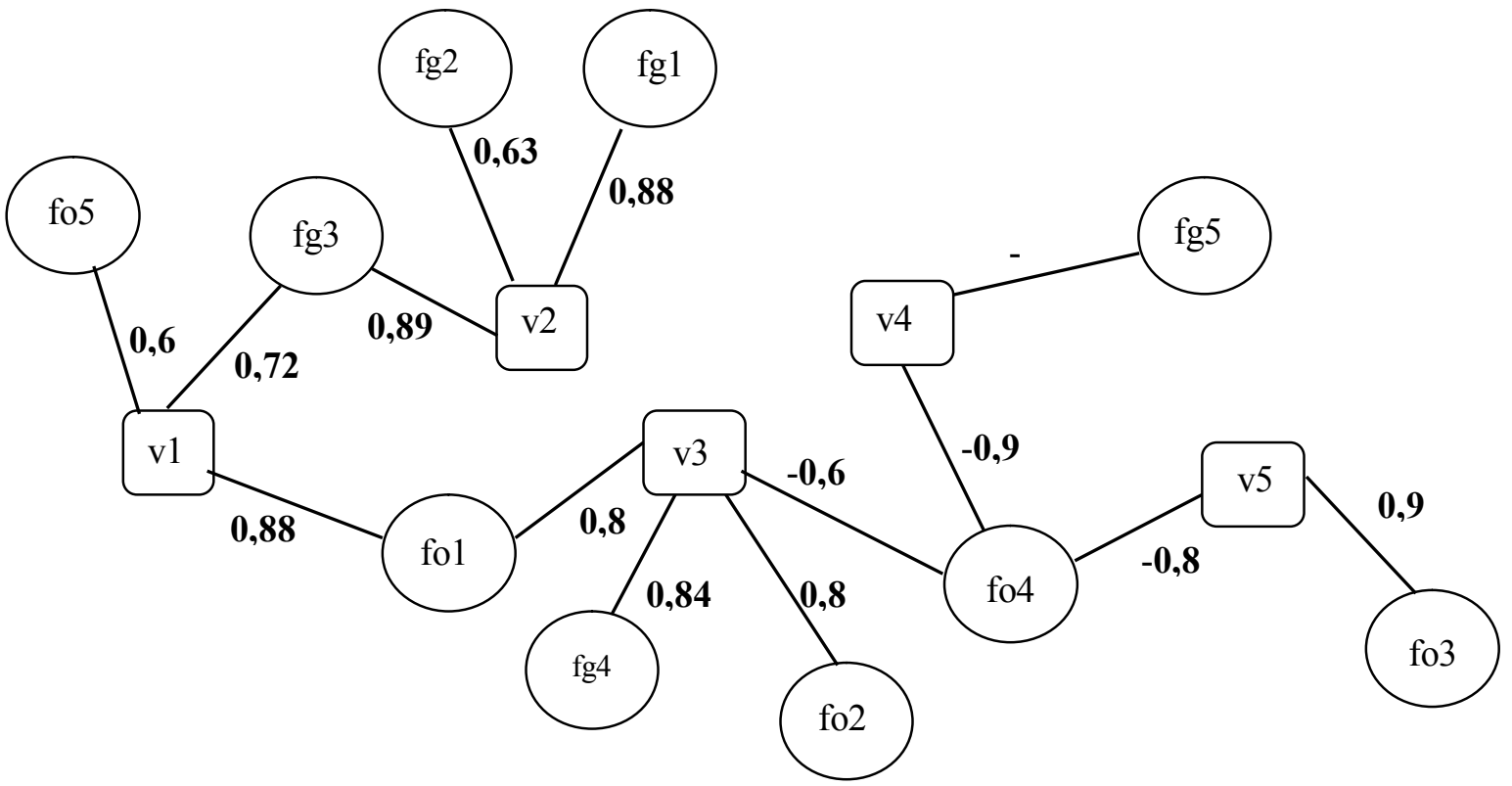

Fig. 1. Correlation Pleiades of the influence of military-geographical and operational-tactical factors of the area of hostilities on the functioning of elements of the AWME recovery system
Prospects for further research in this direction. The successful solution of tasks that are assigned to the recovery system at any level of the hierarchy depends, first of all, on the purposeful management of this system's activities.

The effectiveness of management and, as a result, the effectiveness of the recovery system depends on the ability to analyze the initial data that affects its functioning at the planning stage. geographical and operative-tactical factors of combat area on functioning of elements of system of reconstruction of military-industrial complex and presentation of generalized results in the form of correlation Pleiades makes it possible to draw conclusions about operationaltactical and military-geographical component during preparation and during operation [11].

To summarize the results of the correlation dependence analysis, the method of correlation Pleiades, illustrated in Fig. 1, was applied.

This figure shows the elements shows the elements of the operational-tactical factors set $F O=\left\{f o_{j}\right\}, j=\overline{1, m}, \quad(m=5), \quad$ of the combat area military-geographical factors set $F G=\left\{f g_{j}\right\}, j=\overline{1, m}$, $(m=5)$ and elements of the AWME recovery system $V=\left\{v_{j}\right\}, j=\overline{1, m}, \quad(m=5) \quad$ (statistically significant relationships are taken into account).

The correlative of the influence of militarygeographical and operational-tactical factors of the combat area give the tools of algorithmic consideration of the nature and qualitative characteristics of the influence of factors in the AWME recovery.

According to the authors, taking into account these dependencies in the management of the system will greatly increase the efficiency of its functioning and will provide significant assistance in planning the AWME restoration.
Thus, the results of correlation and factor analysis can be used in the design of decision support systems for the AWME restoration.

\section{Conclusions}

1. Operational-tactical and military-geographical factors for any region have an impact on the functioning of the system for restoring armored weapons and military equipment, different both in terms of semantic 
loads and the results of actions on individual elements of the system.

2. Based on the results of factor analysis, the significance of the influence of each factor can be expressed as a numerical value of the factor load.

3. The influence of both military-geographical and operational-tactical factors of the combat area and the quality of functioning of elements of the recovery system of armored weapons and military equipment correlate with each other.

4. Correlation Pleiades of influence of militarygeographical and operational-tactical factors of the combat area provide tools for managing the renewal of armored weapons and military equipment.

\section{REFERENCES}

1. (2018), The use of repair parts and units. Part 2. Repair and reconstruction of the military unit, National Defense University of Ukraine named after Ivan Cherniakhovskyi, Kyiv, Ukraine, $244 \mathrm{p}$.

2. (2014), Information and analytical materials 64on the implementation of technical support for military units during the execution of tasks in the anti-terrorist operation, National Defense University of Ukraine, Kyiv, Ukraine, $180 \mathrm{p}$.

3. (2014), Analysis of the technical support of the operations of units (units) during the anti-terrorist operation, National Defense University of Ukraine, Kyiv, Ukraine, 220 p.

4. Harman, G. (1972), Modern factor analysis, Translated by Braverman, Statistika, Moscow, Russia, 336 p.

5. Gmurman, V.E. (2005), Probability Theory and Mathematical Statistics, Textbook, manual for universities, Vyssh. shkola, Moscow, $430 \mathrm{p}$.

6. Saati, T.L. (2008), Decision making with dependencies and feedbacks. Analytical Networks, LKI, Moscow, 312 p.

7. Makogon, Ye.A. and Seraya, O.V. (2007), "Evaluation of the effectiveness of complex systems using the modified method of pairwise comparisons", Zbirnyk naukovykh prats Kharkivs'koho universytetu Povitryanykh Syl, no. 3(15), pp. 112-116.

8. Venttsel, Ye.S. (1969), Probability Theory, A Textbook, Nauka, Fizmatgiz, Moscow, SU, 520 p.

9. Monson, H. (1996), Hayes-statistical Digital Signal Processing and Modeling, John Wiley \& Sons, Inc. New York, USA, $264 \mathrm{p}$.

10. Yarovyy, A.T and Strakhov, YE. M. (2015), Multidimensional Statistical Analysis, A Beginner's Guide to Mathematical and Economic Students, Astroprint, Odesa, UA, 240 p.

11. Venttsel, Ye. S. (1972), Operations Research, Sov. Radio, Moscow, SU, 410 p.

Надійшла (reviewed) 30.01.2020

Прийнята до друку (accepted for publication) 15.04.2020

\section{Відомості ПРО АВТOPIB / AвOUT тHE AUTHORS}

Копашинський Сергій Анатолійович - кандидат технічних наук, старший науковий співробітник, начальник кафедри технічного забезпечення інституту оперативного забезпечення та логістики, Національний університет оборони України імені Івана Черняховського, Київ, Україна;

Serhiy Kopashynskii - Candidate of Technical Sciences, Senior Research, Head of Technical Security Institute of Operational Security and Logistics Department, National Defense University of Ukraine named after Ivan Cherniakhovskyi, Kyiv, Ukraine; e-mail: kopashinskyas@gmail.com; ORCID: https://orcid.org/0000-0002-0117-0664

Серпухов Олександр Васильович - кандидат технічних наук, старший науковий співробітник, начальник інституту, Військовий інститут танкових військ Національного технічного університету “ХПI”, Харків, Україна;

Oleksandr Serpukhov - Candidate of Technical Sciences, Senior Research, Head of Institute, Military Institute of Tank Troops of National Technical University "Kharkiv Polytechnic Institute", Kharkiv, Ukraine; e-mail: serpuhov1960@gmail.com; ORCID: https://orcid.org/0000-0002-5029-1016

Макогон Олена Анатоліївна - кандидат технічних наук, доцент кафедри бронетанкового озброєння та військової техніки, Військовий інститут танкових військ Національного технічного університету “ХПІ”, Харків, Україна;

Helen Makogon - Candidate of Technical Sciences, Associate Professor of the Armored vehicles and military equipment Department, Military Institute of Tank Troops of National Technical University “KhPI”, Kharkiv, Ukraine; e-mail: helmkg@ukr.net; ORCID: https://orcid.org/0000-0003-1112-8707

Каракуркчі Ганна Володимирівна - кандидат технічних наук, начальник навчального відділу, Військовий інститут танкових військ Національного технічного університету “ХПІ”, Харків, Україна;

Hanna Karakurkchi - Candidate of Technical Sciences, Head of Study Department, Military Institute of Tank Troops of National Technical University “Kharkiv Polytechnic Institute”, Kharkiv, Ukraine; e-mail: anyutikukr@gmail.com; ORCID: https://orcid.org/0000-0002-1287-3859

Клімов Олексій Петрович - заступник начальника кафедри бронетанкового озброєння та військової техніки, Військовий інститут танкових військ Національного технічного університету “ХПI”, Харків, Україна;

Alexej Klimov - Deputy Head the Armored weapons and military equipment Department, Military Institute of Tank Troops of National Technical University "Kharkiv Polytechnic Institute", Kharkiv, Ukraine; e-mail: klimovaleksej800@gmail.com; ORCID: https://orcid.org/0000-0003-0727-2976

Бабкін Юрій Валерійович - старший викладач кафедри бронетанкового озброєння та військової техніки, Військовий інститут танкових військ Національного технічного університету “ХПІ”, Харків, Україна; 
Yuri Babkin - Senior Lecture of the Armored weapons and military equipment Department, Military Institute of Tank Troops of National Technical University "Kharkiv Polytechnic Institute", Kharkiv, Ukraine; e-mail: yribabkn@gmail.com; ORCID: https://orcid.org/0000-0001-9156-9523

\section{Дослідження впливу}

оперативно-тактичних та воснно-географічних чинників району бойових дій на функціонування елементів системи відновлення бронетанкового озбросння та військової техніки

\section{С. А. Копашинський, О. В. Серпухов, О. А. Макогон, Г. В. Каракуркчі, О. П. Клімов, Ю. В. Бабкін}

Анотація. Предметом вивчення в статті є впливи оперативно-тактичних та воєнно-географічних чинників району бойових дій на функціонування елементів системи відновлення бронетанкового озброєння та військової техніки під час ведення бойових дій в сучасних умовах. Метою дослідження $є$ дослідження кореляційних впливів оперативнотактичних і воєнно-географічних чинників району бойових дій на функціонування системи відновлення бронетанкового озброєння та військової техніки. Завдання: проаналізувати впливи чинників району бойових на функціонування системи відновлення бронетанкового озброєння та військової техніки під час виконання ЗСУ завдань за призначенням; сформувати формальні множини умов і чинників та елементів і функціональних зв'язків системи відновлення бронетанкового озброєння та військової техніки, що підпадають під їх вплив; обчислити факторні навантаження кожного чинника та побудувати кореляційні плеяди впливовості. Методологічною основою дослідження стали загальнонаукові та спеціальні методи наукового пізнання. Були використані метод аналізу ієрархій, математичний апарат теорії імовірності та багатовимірного статистичного аналізу. Отримані такі результати. Оперативно-тактичні та воєнно-географічні чинники району бойових дій та елементи і функціональні зв'язки системи відновлення бронетанкового озброєння та військової техніки формально представлені у вигляді множин випадкових величин, а суттєвість впливу кожного чинника виражена числовою величиною факторного навантаження. За результатами кореляційного та факторного аналізу побудовані кореляційні плеяди, які дають інструментарій алгоритмічного врахування сутності та якісних характеристик впливу чинників при управлінні відновленням бронетанкового озброєння та військової техніки. Висновки. Оперативно-тактичні і воєнно-географічні чинників для будь-якої регіону мають впливи на функціонування системи відновлення бронетанкового озброєння та військової техніки, різні як за змістовним навантаженням так і за наслідками дій на окремі елементи системи. За результатами факторного аналізу суттєвість впливу кожного чинника може бути виражена числовим значенням величини факторного навантаження. Впливовості як воєнно-географічних, так і оперативно-тактичних чинників району бойових та якість функціонування елементів системи відновлення бронетанкового озброєння та військової техніки корелюють між собою. Кореляційні плеяди впливовості воєнно-географічних i оперативно-тактичних чинників району бойових дають інструментарій при управлінні відновленням бронетанкового озброєння та військової техніки.

Ключов і слов а : відновлення бронетанкового озброєння та військової техніки; оперативно-тактичні та воєнногеографічних чинники району бойових дій; факторний аналіз; кореляційні плеяди.

\section{Исследование влияния}

оперативно-тактических и военно-географических факторов района боевых действий

на функционирования элементов системы восстановления бронетанкового вооружения и военной техники

С. А. Копашинский, А. В. Серпухов, Е. А. Макогон, А. В. Каракуркчи, А. П. Климов, Ю. В. Бабкин

Ан нотация. Предметом изучения в статье является влияния оперативно-тактических и военно-географических факторов района боевых действий на функционирование элементов системы восстановления бронетанкового вооружения и военной техники во время ведения боевых действий в современных условиях. Целью исследования является исследование корреляционных воздействий оперативно-тактических и военно-географических факторов района боевых действий на функционирование системы восстановления бронетанкового вооружения и военной техники. Задачи: проанализировать влияние факторов района боевых на функционирование системы восстановления бронетанкового вооружения и военной техники во время выполнения ВСУ задач по назначению; сформировать формальные множества условий и факторов, элементов и функциональных связей системы восстановления бронетанкового вооружения и военной техники, подпадающих под их влияние; вычислить факторные нагрузки каждого фактора и построить корреляционные плеяды влияния. Методологической основой исследования стали общенаучные и специальные методы научного познания. Были использованы метод анализа иерархий, математический аппарат теории вероятности и многомерного статистического анализа. Получены следующие результаты. Оперативнотактические и военно-географические факторы района боевых действий, элементы и функциональные связи системы восстановления бронетанкового вооружения и военной техники формально представлены в виде множеств случайных величин, а существенность влияния каждого фактора выражена числовой величиной факторного нагрузки. По результатам корреляционного и факторного анализа построены корреляционные плеяды, которые дают инструментарий алгоритмического учета сущности и качественных характеристик влияния факторов при управлении восстановлением бронетанкового вооружения и военной техники. Выводы. Оперативно-тактические и военно-географические факторы для любого региона имеют влияния на функционирование системы восстановления бронетанкового вооружения и военной техники, разные как по факторной содержательной нагрузке, так и по результатам действий на отдельные элементы системы. По результатам факторного анализа сущность влияния каждого фактора может быть выражена числовым значением величины факторного нагрузки. Влияние как военно-географических, так и оперативнотактических факторов района боевых и качество функционирования элементов системы восстановления бронетанкового вооружения и военной техники коррелируют между собой. Корреляционные плеяды влияния военно-географических и оперативно-тактических факторов района боевых дают инструментарий при управлении восстановлением бронетанкового вооружения и военной техники.

Ключевые слова: восстановление бронетанкового вооружения и военной техники; оперативно-тактические и военно-географических факторов района боевых действий; факторный анализ; корреляционные плеяды. 